СИНТЕЗ ТА АНАЛІЗ БІОЛОГІЧНО АКТИВНИХ РЕЧОВИН

\title{
THE CHROMATOGRAPHIC STUDY OF THE EXTRACTS OF GLIBENCLAMIDE, GLICLAZIDE AND GLIMEPIRIDE OBTAINED FROM BIOLOGICAL OBJECTS
}

\author{
T.V.Kucher, S.I.Merzlikin \\ National University of Pharmacy \\ Key words: drugs; sulphonylurea derivatives; chemico-toxicological analysis; biological objects; \\ methods of isolation; TLC method
}

\begin{abstract}
This article presents the results of the standardized conditions elaboration for detection and identification of sulfonylureas derivatives (SUD) such as glibenclamide, gliclazide and glimepiride obtained by chromatographing of their extracts from the liver tissues using TLC method. The isolation of SUD from a biological object has been conducted with the help of general methods for chemico-toxicological analysis of drugs such as extraction with water acidified by oxalic acid according to Vasileva method and extraction with ethanol acidified by oxalic acid according to Stas-Otto method. The chloroform extracts obtained have been examined according to the methodology of TLC-screening of drugs in two stages. At the first stage ethyl acetate as the common mobile phase was used, and at the second stage - the special systems for the substances studied such as ethyl acetate - glacial acetic acid (49.5:0.5) and methylene chloride - ethyl acetate - glacial acetic acid (50:50:1). For detection of their adsorption zones the specific reagents were used: $1 \%$ solution of vanillin and $5 \%$ solution of chloral hydrate. It has been found that the chloroform extracts of SUD previously introduced in the model sample of the liver in the concentration of $20 \mathrm{mg}$ per $50 \mathrm{~g}$ of the biological object and isolated from this sample by Stas-Otto method have satisfactory Rf values that meet the chromatographic parameters of $R f$ values of the standard substances. However, when chromatographing the chloroform extracts of SUD introduced in the biological object in the same concentration and isolated from it by Vasileva method the absorption zones in the thin layer have not been found. With increase in concentrations of the compounds studied to $50 \mathrm{mg}$ per $50 \mathrm{~g}$ of the biological object and subsequent chromatography of the corresponding chloroform extracts obtained by Vasileva method, their Rf value did not correspond to the chromatographic parameters of the standard substances. Thus, the application of Vasileva method to obtain the extracts of the SUD under study from the liver tissues has a negative impact on their detection sensitivity and parameters of the chromatographic mobility in the thin layer. It has been determined that the proposed and standardized conditions for detection and identification of SUD drugs by TLC are suitable for chemico-toxicological analysis of chloroform extracts obtained from the liver tissues by Stas-Otto method.
\end{abstract}

Sulfonylurea derivatives (SUD) - glibenclamide, gliclazide and glimepiride form the base of treatment for type 2 diabetes mellitus $[1,8,10]$. The features of their use are specificity of the group (older patients), OTC availability, polypragmasia and other factors, which form their toxicological hazard. These factors cause development of side effects, which lead to the acute or lethal poisoning. As a rule, side effects of the toxic nature are developed with the doses that are higher than the therapeutic ones, while the lethal poisoning occurs most frequently due to intentional (suicide) drug overdose with further development of hypoglycemia, lactic acidosis, cardiovascular events, and other pathological complications [9-14]. Thus, the websites of FDA and patientsville.com highlight 182 cases of lethal poisoning with this drug in the world during the period from 2010 to 2013.
Thin layer chromatography (TLC) is one of the most applied instrumental methods used at different stages of the chemico-toxicological analysis (CTA) when poisoning with drugs for their detection and identification in the extracts from biological objects $[2,3,6]$. The extracts obtained after isolation of toxicants from biological objects are commonly contaminated with different impurities. Their presence in the extract can affect the chromatographic mobility of these substances. In such cases, it is necessary to conduct pre-standardization of the chromatographic conditions proposed using standard samples of the toxicants.

In our previous chromatographic investigations of glibenclamide and gliclazide the general and specific chromogenic reagents for their identification were determined [4], as well as the conditions for selective sepa- 
ration of these substances in a thin layer of the sorbent were developed and standardized [5].

Therefore, the aim of the work was to develop the standardized conditions for detection and identification of glibenclamide, gliclazide and glimepiride by TLC using their extracts from biological objects obtained by general methods for chemico-toxicological analysis of drugs.

\section{Materials and Methods}

The method for preparation of test solutions of glibenclamide and glimepiride. Place approximately $20.0 \mathrm{mg}$ of the standard sample of glibenclamide or glimepiride (for isolation by Stas-Otto method) and $20.0 \mathrm{mg}$ and $50.0 \mathrm{mg}$ of the standard sample glibenclamide or glimepiride (for isolation by Vasileva method) into a $10 \mathrm{ml}$ volumetric flask, add $3.0 \mathrm{ml}$ of methanol - methylene chloride mixture $(1: 1)$ and mix.

The method for preparation of test solution of gliclazide. Place approximately $20.0 \mathrm{mg}$ of the standard sample of gliclazide (for isolation by Stas-Otto method) and $20.0 \mathrm{mg}$ and $50.0 \mathrm{mg}$ of the standard sample of gliclazide (for isolation by Vasileva method) into a $10 \mathrm{ml}$ volumetric flask, add $3.0 \mathrm{ml}$ of chloroform and mix.

The method of isolation of glibenclamide, gliclazide and glimepiride by method Vasileva. Place $50 \mathrm{~g}$ of the chopped pig liver in a flask, add $3 \mathrm{ml}$ of the test solution of the corresponding drug of SUD. Stir the mixture carefully and allow to stand for $24 \mathrm{~h}$. The isolation of the drugs studied from the mixture obtained is done with water acidified by oxalic acid according to the method [2]. Further the chloroform extracts obtained are studied by TLC.

The method of isolation of glibenclamide, gliclazide and glimepiride by Stas-Otto method. Place $50 \mathrm{~g}$ of the chopped pig liver in a flask, add $3 \mathrm{ml}$ of the test solution of the corresponding drug of SUD. Stir the mixture carefully and allow to stand for $24 \mathrm{~h}$. The isolation of the drugs studied from the mixture obtained is done with ethanol acidified by oxalic acid according to the method [2]. Further the chloroform extracts obtained are studied by TLC.

The chromatographic conditions. The study was performed on Merck silica gel $60 \mathrm{~F}_{254}$ chromatographic plates (Germany) and Sorbfil (Russian Federation) with the size of $10 \times 10 \mathrm{~cm}$. Before eluating the samples the chromatographic plates were previously washed with methanol and activated in a drying cabinet at $110-120^{\circ} \mathrm{C}$ for half an hour. The following systems of solvents were used as mobile phases: 1) ethyl acetate; 2) ethyl acetate glacial acetic acid (49.5:0.5); 3) methylene chloride ethyl acetate - glacial acetic acid (50:50:1). Among them: system 1 is the system for common TLC-screening of drugs of the acidic nature recommended by the International Association of Forensic Toxicologists (TIAFT); systems 2 and 3 are special systems proposed by the authors for identification of the substances of SUD studied. For detection of the adsorption zones of the substances under research such reagents as $1 \%$ solution of vanillin and $5 \%$ solution of chloral hydrate were used.

The chromatographic procedure. The analysis was performed in a standard chromatographic chamber pre- viously saturated with eluent vapours for $30 \mathrm{~min}$. The chloroform extracts of SUD (1-2 ml) obtained from the liver tissues were evaporated to the minimal volume of $0.05 \mathrm{ml}$. At the starting line of the chromatographic plate previously activated $5 \mu \mathrm{L}$ of the corresponding extracts of the drugs studied was applied with a glass capillary. Five $\mu \mathrm{L}(1 \mu \mathrm{g}$ in the sample) of the test solutions of the corresponding drugs was applied at the distance of $1 \mathrm{~cm}$. The chromatographic plate was placed into the chamber with the corresponding mixture of solvents and eluated. When the solvent front passed $8 \mathrm{~cm}$ from the starting line, the plate was removed from the chamber, air-dried, examined under UV-light at $254 \mathrm{~nm}$ and treated with the corresponding reagents.

\section{Results and Discussion}

According to the literature sources [9, 12-14], lethal poisonings with drugs of SUD are primarily associated with suicidal overdose in the doses that are 5 to 10 times higher than the therapeutic ones depending on the circumstances. When taking per os and after absorption these drugs undergo biotransformation in the liver with formation of active and inactive metabolites. According to the pharmacokinetic data the half-life of glibenclamide and glimepiride is from 5 to 8 hours, and gliclazide from 20 to 40 hours [1]. Therefore, in the first hours after death in the liver tissues of an injured person a certain concentration of SUD in a native (unaltered) form can be detected at the level of concentrations of the corresponding metabolite; based on the data of the sources [9, 12-14] it can be up to $20 \mathrm{mg}$ equivalent to $50 \mathrm{~g}$ of the biological object. It is this concentration of glibenclamide, gliclazide or glimepiride that we proposed for their introduction into the model sample of the biological object selected. Considering the physical and chemical properties of SUD (solubility in organic solvents and insolubility in water, pKa 5.3-6.2) their isolation from the liver tissues was performed by general methods for CTA of drugs, namely extraction with water acidified by oxalic acid according to Vasileva method and extraction with ethanol acidified by oxalic acid according to Stas-Otto method [2]. The chloroform extracts obtained were studied in the conditions standardized by authors [5] according to the methodology of TLC-screening of drugs in two stages [7]. At the first stage of our research ethyl acetate (system 1) was used as the common mobile phase for the substances of the acidic and neutral character, and at the second stage the special systems 2 and 3 for the substances studied such as ethyl acetate - glacial acetic acid (49.5:0.5) and methylene chloride - ethyl acetate - glacial acetic acid (50:50:1), respectively.

It has been found that after chromatography of the chloroform extracts of SUD obtained by Stas-Otto method and the treatment of the thin layer with reagents specific for this group of substances the coloured spots with the Rf values relative to standard substances were clearly identified on the chromatographic plates. However, after chromatography of the chloroform extracts of SUD obtained by Vasileva method the adsorption zones corresponding to these substances in the thin layer were 
Parameters of the chromatographic mobility of the substances studied

\begin{tabular}{|c|c|c|c|c|c|c|c|c|c|c|c|c|c|c|c|c|c|c|}
\hline \multirow{4}{*}{ 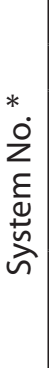 } & \multicolumn{18}{|c|}{ Rf values } \\
\hline & \multicolumn{6}{|c|}{ glibenclamide } & \multicolumn{6}{|c|}{ gliclazide } & \multicolumn{6}{|c|}{ glimepiride } \\
\hline & \multicolumn{2}{|c|}{$\begin{array}{l}\text { Standard } \\
\text { sample }\end{array}$} & \multicolumn{2}{|c|}{$\begin{array}{c}\text { Extracted } \\
\text { by Vasileva } \\
\text { method }\end{array}$} & \multicolumn{2}{|c|}{$\begin{array}{c}\text { Extracted } \\
\text { by Stas- } \\
\text { Otto } \\
\text { method }\end{array}$} & \multicolumn{2}{|c|}{$\begin{array}{l}\text { Standard } \\
\text { sample }\end{array}$} & \multicolumn{2}{|c|}{$\begin{array}{c}\text { Extracted } \\
\text { by Vasileva } \\
\text { method }\end{array}$} & \multicolumn{2}{|c|}{$\begin{array}{c}\text { Extracted } \\
\text { by Stas- } \\
\text { Otto } \\
\text { method }\end{array}$} & \multicolumn{2}{|c|}{$\begin{array}{l}\text { Standard } \\
\text { sample }\end{array}$} & \multicolumn{2}{|c|}{$\begin{array}{l}\text { Extracted } \\
\text { by Vasileva } \\
\text { method }\end{array}$} & \multicolumn{2}{|c|}{$\begin{array}{c}\text { Extracted } \\
\text { by Stas- } \\
\text { Otto } \\
\text { method }\end{array}$} \\
\hline & 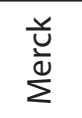 & 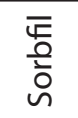 & 炫 & $\begin{array}{l}\overline{\bar{c}} \\
\text { o } \\
\text { b }\end{array}$ & 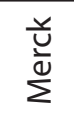 & $\begin{array}{l}\bar{c} \\
\text { on } \\
\text { ㅎํㄴ }\end{array}$ & $\frac{\stackrel{u}{u}}{\sum}$ & $\begin{array}{l}\text { 든 } \\
\text { oñँ } \\
\text { in }\end{array}$ & 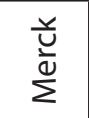 & $\begin{array}{l}\bar{c} \\
\text { oñ } \\
\text { ì }\end{array}$ & 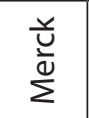 & $\begin{array}{l}\bar{c} \\
\text { o } \\
\text { bे }\end{array}$ & $\frac{⿱ 亠 䒑}{\frac{u}{U}}$ & $\begin{array}{l}\bar{c} \\
\text { 음 } \\
\text { ज }\end{array}$ & 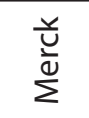 & $\begin{array}{l}\bar{c} \\
\text { o } \\
\text { bे }\end{array}$ & $\frac{\text { Ù }}{\stackrel{u}{u}}$ & $\begin{array}{l}\bar{c} \\
\text { 훔 } \\
\text { in }\end{array}$ \\
\hline 1 & 0.47 & 0.42 & 0.35 & 0.30 & 0.46 & 0.43 & 0.48 & 0.44 & 0.38 & 0.36 & 0.47 & 0.46 & 0.46 & 0.40 & 0.36 & 0.34 & 0.45 & 0.41 \\
\hline 2 & 0.64 & 0.63 & 0.57 & 0.56 & 0.65 & 0.65 & 0.73 & 0.74 & 0.67 & 0.64 & 0.70 & 0.70 & 0.66 & 0.67 & 0.60 & 0.59 & 0.65 & 0.63 \\
\hline 3 & 0.56 & 0.56 & 0.50 & 0.50 & 0.55 & 0.56 & 0.66 & 0.68 & 0.57 & 0.57 & 0.66 & 0.67 & 0.50 & 0.52 & 0.45 & 0.46 & 0.50 & 0.51 \\
\hline
\end{tabular}

Notes. ${ }^{*}$ - numbering of the systems according to the list presented above.

not identified. These results can be explained by a lower degree of extraction of SUD acidified with water compared to extraction acidified with ethanol due to the peculiarities of physical and chemical properties of the substances studied. With the purpose of improving detection sensitivity of SUD isolated from the liver tissues by Vasileva method the concentration in biological objects up to $50 \mathrm{mg}$ per $50 \mathrm{~g}$ of the liver weight was increased. The results obtained are given in Table.

When chromatographing SUD extracts obtained by Stas-Otto method in the solvent system 1 the $\mathrm{Rf}$ values on Merck (0.45-0.47) and Sorbfil (0.41-0.46) plates were correlative with the $\mathrm{Rf}$ values of their standard samples (0.46-0.48 and 0.40-0.44, respectively). Such trend is also observed when chromatographing the corresponding extracts in the solvent systems 2 and 3 . However, when chromatographing extracts of SUD obtained by Vasileva method in system 1 the Rf values of these substances on Merck (0.35-0.36) and Sorbfil (0.30-0.36) plates did not correspond to the Rf values of the standard samples. It can be explained by the influence of endogenous substances on the research results because Vasileva method does not involve purification of extracts from the biological material from proteins. This tendency is also observed when chromatographing the corresponding extracts obtained by Vasileva method in the solvent systems 2 and 3.
The colouring of the adsorption zones of the substances under study after treatment of chromatographic plates with the reagents specific for SUD was correlative with the results obtained by the authors in standardization of the chromatographic conditions [5]. In particular, $1 \%$ solution of vanillin with glibenclamide formed a violet colour, with gliclazide - a dark blue colour and with glimepiride - a brown colour, and 5\% solution of chloral hydrate - a green brown, dark brown and red colour, respectively.

CONCLUSIONS

1. The elaboration of the standardized conditions for detection and identification of glibenclamide, gliclazide and glimepiride by TLC using their extracts from the liver tissues obtained by general methods for CTA of drugs, namely Vasileva and Stas-Otto methods, has been performed.

2. It has been found that the application of Vasileva method to obtain the extracts of the substances of SUD under study from the liver tissues has a negative impact on their detection sensitivity and parameters of the chromatographic mobility in the thin layer of the sorbent.

3. It has been determined that the proposed and standardized conditions for detection and identification of drugs from SUD by TLC are suitable for chemico-toxicological analysis of chloroform extracts obtained from the liver tissues by Stas-Otto method.

\section{REFERENCES}

1. Белоусов Ю.В. Клиническая фармакология и фармакотерапия. - М.: Медииинское информаичонное агентство, 2010. $-884 \mathrm{c}$.

2. Вергейчик Т.Х. Токсикологическая химия: Учебник. - М.: МЕДпресс-информ, 2009. - 400 c.

3. Карташов В.А., Чернова Л.В. Химико-токсикологический анализ: в 2-х ч. - Ч. 1. Выделение токсических веществ из биологических объектов. - Майкоп: ООО «Качество», 2008. - $188 \mathrm{c}$.

4. Кучер Т.В., Мерзликин С.И. // Фармация Казахстана. - 2014. - №7. - С. 35-37.

5. Кучер Т.В., Мерзлікін С.І. // Управління, економіка та забезпечення якості в фармації. - 2015. - №1. C. $8-13$.

6. Мерзликин С.И., Журавель И.А., Москаленко В.Ю. Лекиии по токсикологической химии (мультимедиа презентация) для студентов факультета подготовки иностранных граждан и заочной (дистанционной) формы обучения специальности «Фармачия». - Х.: Издатель Савчук О.О., 2015. - 226 с. 
7. Раменская Г.В., Родионова Г.М., Кузнецова Н.И. ТСХ-скрининг токсикологически значимых соединений, изолируемых экстракичией и сорбичей. - М.: ГЭОТАР-Медиа, 2010. - 240 c.

8. Germanyuk T.A., Ivko T.I. // Вісник фармаціï. - 2014. - №3(79) - C. 78-82.

9. Henry K., Harris C.R. // Pediatr. Clin. N. Am. - 2006. - Vol. 53. - P. 293-315.

10. Nyenwe E.A., Jerkins T.W., Umpierrez G.E., Ki A.E. // Metab. Clin. Experim. - 2011. - Vol. 60, №1. - P. 1-23.

11. Sadikot S.M., Mogensen C.E. // Diabetes Res. Clin. Pract. - 2008. - Vol. 82, №1. - P. 391-395.

12. Schramm T.K., Gislason G.H., Vaag A. // Eur. Heart J. - 2011. - Vol. 32, №9. - P. 1900-1908.

13. Side_effects [Електронний ресурс]:-Pежим достуny: http://www.patientsville.com/medication/side_effects.

14. Zoungas S., Patel A., Chalmers J. // N. Engl. J. Med. - 2010. - Vol. 363, №5. - P. 1410-1418.

ХРОМАТОГРАФІЧНЕ ДОСЛІДЖЕННЯ ВИЛУЧЕНЬ ГЛІБЕНКЛАМІДУ, ГЛІКЛАЗИДУ ТА ГЛІМЕПІРИДУ 3 БІОЛОГІЧНИХ ОБ'ЄКТІВ

\section{Т.В.Кучер, С.І.Мерзлікін}

Ключові слова: лікарські засоби; похідні сульфронілсечовини; хіміко-токсикологічний аналіз;

біологічні об'єкти; методи ізолювання; метод ТШХ

Висвітлені результати стосовно опрацювання стандартизованих авторами умов виявлення та ідентифрікації похідних сульфонілсечовини (ПСС): глібенкламіду, гліклазиду та глімепіриду, які були одержані при хроматографуванні їх вилучень з тканин печінки методом ТШХ. Для ізолювання ПСС з біологічного об'єкту застосовували загальні для хіміко-токсикологічного аналізу лікарських речовин методи: підкисленою водою (метод Васильєвої) та підкисленим етанолом (метод Cтаса-Ommо). Одержані хлорофрормні екстракти ПСС хроматографували в тонкому шарі відповідно до методології ТШХ-скринінгу лікарських речовин у два етапи. На першому етапі досліджень як загальну рухому фразу використовували етилацеmam, а на другому - спеціальні для досліджуваних сполук системи: етилацетат-кислота ацетатна льодяна $(49,5: 0,5)$ та метиленхлорид-етилацетат-кислота ацетатна льодяна (50:50:1). Для виявлення зон їх адсорбції використовували специфічні реагенти: 1\% розчин ваніліну та 5\% розчин хлоралгідрату. Встановлено, що при хроматографуванні хлорофоормних екстрактів ПСС, попередньо уведених у модельний зразок печінки в концентрації 20 мг на 50 г біологічного об'єкту та виділених з останнього методом Cmaca-Отmо, їх значення Rf задовільно відповідали хроматографрічним параметрам відповідних стандартних речовин. Проте при хроматографуванні хлороформних екстрактів ПСС, уведених у біологічний об’єкт в аналогічній концентрації та виділених з нього методом Васильєвої, зони їх адсорбції у тонкому шарі не виявлені. При збільшенні концентрації досліджуваних сполук до 50 мг на 50 г біологічного об'єкту та хроматографруванні відповідних хлорофрормних екстрактів, одержаних методом Васильєвої, їх значення Rf не відповідали хроматографічним параметрам відповідних стандартних речовин. Отже, застосування методу Васильєвої для ізолювання досліджуваних ПСС з тканин печінки негативно впливає на чутливість їх виявлення та параметри хроматографічної рухливості в тонкому шарі сорбенту. Запропоновані та стандартизовані умови виявлення та ідентифікації лікарських речовин ПСС методом ТШХ визначені придатними для хіміко-токсикологічного дослідження їх хлорофоормних екстрактів, одержаних з тканин печінки методом Cтаса-Ommо.

\section{ХРОМАТОГРАФИЧЕСКОЕ ИССЛЕДОВАНИЕ ИЗВЛЕЧЕНИЙ ГЛИБЕНКЛАМИДА, ГЛИКЛАЗИДА И ГЛИМЕПИРИДА ИЗ БИОЛОГИЧЕСКИХ ОБЪЕКТОВ Т.В.Кучер, С.И.Мерзликин}

Ключевые слова: лекарственные средства; производные сульфонилмочевины; химикотоксикологический анализ; биологические объекты; методы изолирования; метод ТСX Освещены результаты по апробированию стандартизированных авторами условий обнаружения и идентификации производных сульфонилмочевины (ПСМ): глибенкламида, гликлазида и глимепирида, которые были получены при хроматографировании их извлечений из тканей печени методом ТСХ. Для изолирования ПСМ из биологического объекта применяли общие для химико-токсикологического анализа лекарственных веществ методы: подкисленной водой (метод Васильевой) и подкисленным этанолом (метод Cmaca-Оmmо). Полученные хлороформные экстракты ПСМ хроматографировали в тонком слое в соответствии с методологией ТСХ-скрининга лекарственных веществ в два этапа. На первом этапе исследований как общую подвижную фразу использовали этилацетат, а на втором - специальные для исследуемых соединений системы: этилацетат-кислота уксусная ледяная $(49,5: 0,5)$ u метиленхлорид-этилацетат-кислота уксусная ледяная (50:50:1). Для обнаружения зон их адсорбции использовали специфические реагенты: 1\% раствор ванилина и 5\% раствор хлоралгидрата. Установлено, что при хроматографировании хлороформных экстрактов ПСМ, предварительно введенных в модельный образец печени в концентрации 20 ма на 50 г биологического объекта и выделенных из последнего методом Cmaca-Ommo, их значения Rf удовлетворительно отвечали хроматографическим параметрам соответствующих стан- 
дартных веществ. Однако при хроматографировании хлорофрормных экстрактов ПСМ, введенных в биологический объект в аналогичной концентрации и выделенных из него методом Васильевой, зоны их адсорбции в тонком слое не обнаружены. При увеличении концентрации исследуемых соединений до 50 мг на 50 г биологического объекта и хроматографировании соответствующих хлороформных экстрактов, полученных методом Васильевой, их значения Rf не соответствовали хроматографическим параметрам соответствующих стандартных веществ. Таким образом, применение метода Васильевой для изолирования исследуемых ПСМ из тканей печени негативно влияет на чувствительность их обнаружения и параметры хроматографрической подвижности в тонком слое сорбента. Предложенные и стандартизированные условия обнаружения и идентифрикации лекарственных веществ ПСМ методом ТСХ определены приемлемыми для химико-токсикологического исследования их хлороформных экстрактов, полученных из тканей печени методом Cтаса-Oтmо. 